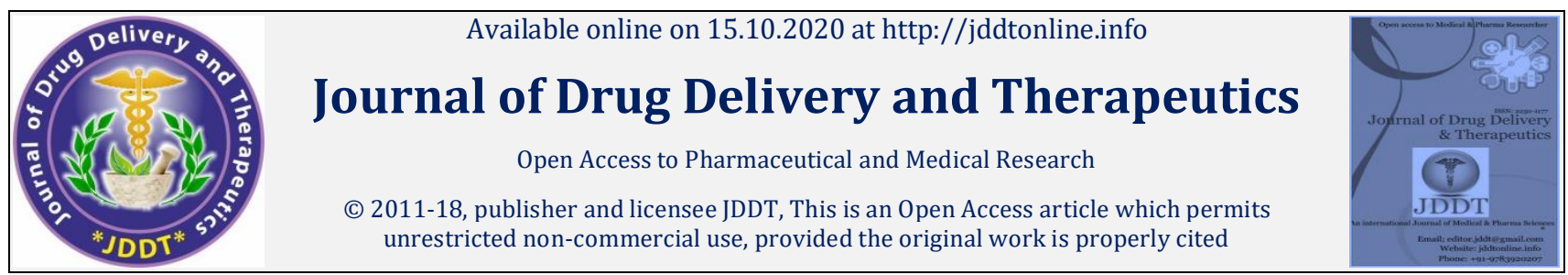

Open $\odot$ Access

Research Article

\title{
Acute and Subacute Oral Toxicity Studies and Anti-Sickling Activity Assessment of FACA ${ }^{\circledR}$ Syrup
}

\author{
OUEDRAOGO Geoffroy Gueswindé1*, ILBOUDO Sylvain1,2, OUEDRAOGO Salfo1, OUEDRAOGO Jean Claude Romaric

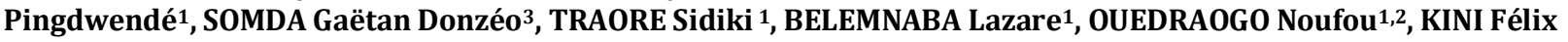 \\ Bondo', LOMPO Marius', GUISSOU Innocent Pierre ${ }^{4}$, OUEDRAOGO Sylvin'1
}

\footnotetext{
${ }^{1}$ Département de Médecine et Pharmacopée Traditionnelles et Pharmacie, Institut de Recherche en Sciences de la Santé, Centre Na tional de la Recherche Scientifique et Technologique (MEPHATRA-PH/IRSS/CNRST), 03 BP 7047 Ouagadougou 03, Burkina Faso.

2 Unité Mixte de Recherche Internationale - Environnement, Santé, Sociétés (UMI 3189, ESS) CNRST/CNRS/UCAD/UGB/USTTB, Burkina Faso.

${ }^{3}$ Laboratoire du Développement du Médicament, Ecole Doctoral de Santé, Université Joseph KI-ZERBO, 03 BP 7021 Ouagadougou 03, Burkina Faso

${ }^{4}$ Université Saint Thomas d'Aquin, 06 BP 10212 Ouagadougou 06, Burkina Faso
}

\begin{abstract}
Sickle cell disease remains a major public health problem in Burkina Faso and Africa. For the management of this pathology in young children, the Institute for Research in Health Sciences has developed an herbal drug called FACA ${ }^{\circledR}$ syrup. The objective of this study was to verify the safety and pharmacological efficacy of this formulation for its use in the management of sickle cell disease. Acute and subacute oral toxicity tests were performed on Wistar rats in accordance with Organization for Economic Cooperation and Development test guidelines and anti-sickling activity of $\mathrm{FACA}^{\circledR}$ syrup was evaluated according to the Emmel test. In the acute test, FACA ${ }^{\circledR}$ syrup didn't cause mortality or any behavioral change at dose of $2000 \mathrm{mg} / \mathrm{kg} / \mathrm{b} . \mathrm{w}$ suggesting that the test product estimated LD50 is $5000 \mathrm{mg} / \mathrm{kg}$ b.w. The results of subacute toxicity study indicate that the daily administration of FACA ${ }^{\circledR}$ syrup during 28 days did not result in significant change on physical, haematological and biochemical parameters up to dose of $1000 \mathrm{mg} / \mathrm{kg}$ b.w. The evaluation of effect of FACA ${ }^{\circledR}$ syrup in vitro on sickling revealed that, FACA ${ }^{\circledR}$ syrup possesses a real antisickling activity. Regarding these results FACA ${ }^{\circledR}$ syrup would be considered as safe in both acute and subacute exposure and could be used in the management of sickle cell dis eases.
\end{abstract}

Keywords: FACA® syrup, oral toxicity, sickle cell anemia, Antisickling activity

Article Info: Received 09 Aug 2020; $\quad$ Review Completed 11 Sep 2020; $\quad$ Accepted 19 Sep 2020; Available online 15 Oct 2020

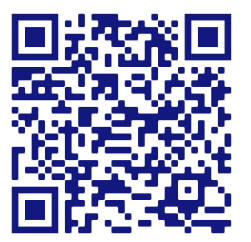

Cite this article as:

Ouedraogo GG, Ilboudo S, Ouedraogo S, Ouedraogo JCRP, Somda GD, Traore S, Belemnaba L, Ouedraogo N, Kini FB, Lompo M, Guissou IP, Ouedraogo S, Acute and Subacute Oral Toxicity Studies and Anti-Sickling Activity Assessment of FACA ${ }^{\circledR}$ Syrup, Journal of Drug Delivery and Therapeutics. 2020; 10(5-s):40-50 http://dx.doi.org/10.22270/jddt.v10i5-s.4336

OUEDRAOGO Geoffroy Gueswindé, Département de Médecine et Pharmacopée Traditionnelles et Pharmacie, Institut de Recherche en Sciences de la Santé, Centre National de la Recherche Scientifique et Technologique (MEPHATRA-PH/IRSS/CNRST), 03 BP 7047 Ouagadougou 03, Burkina Faso

\section{INTRODUCTION}

Traditional medicine (TM), also known as complementary medicine (CM), is the primary mode of health care delivery or used as a complement to it around the world 1. Medicine and traditional pharmacopoeia remain the first resort for nearly $80 \%$ of African populations for their health needs ${ }^{2}$. Several factors including socio-cultural beliefs, ease of access, and low income of the populations faced with the high costs of conventional medicines explain this renewed interest in traditional medicine 1 . Regarding this situation, nearly 40 African countries have developed national traditional medicine policies in an attempt to best meet the needs of their populations. In addition, more than 28 national research institutes are currently conducting research on traditional medicine products used in the treatment of malaria, HIV / AIDS, sickle cell disease, diabetes and hypertension 1 . This is the case of the Institute for Research in Health Sciences (IRSS) through its department of medicine and traditional pharmacopoeia, pharmacy (MEPHATRA / PH) which has been carrying out research since decades for the development of phytomedicines from traditional knowledge for the management of priority public health pathologies including sickle cell disease. 
Sickle cell disease (SCD) or sickle cell anemia is a group of disorders that affects hemoglobin. It is a genetic disease in which red blood cells contain hemoglobin $\mathrm{S}$ (HbS), an abnormal form of the protein that carries oxygen. People who inherit the sickle cell genes from both parents are homozygous and develop SCD, while those who inherit the gene from only one parent have the sickle cell trait. Those who have the trait are carriers, have no symptoms, but can pass the gene on to their offspring ${ }^{3}$. Sickle cell disease is the most common genetic disease in the African Region ${ }^{4}$. It remains a major public health problem in Burkina Faso and Africa. The prevalence rate reaching between 10 and $40 \%$ in populations of certain regions 5 . Each year, nearly $2 \%$ of newborns are affected by the disease and 50 to $75 \%$ of them die before the age of 5 6,7. To deal with this pathology, research carried out by the IRSS has led to the development of an herbal drug called FACA ${ }^{\circledR}$ in form of capsule and used for the management of sickle cell disease(8). FACA which is a combination of powder from roots barks of two plants, Zanthoxylum zanthoxyloides Lam (Rutaceae) (Z. zanthoxyloides) and Calotropis procera (Ait) R.Br (Apocynaceae) (C. procera), possess anti-sickling activity in vitro and clinically effective on SCD in humans $8-10$. This herbal drug obtained its marketing authorization in 2010 and was included on the list of essential drugs in 2011 in Burkina Faso 11. It meets the needs of the population in terms of sickle cell disease management. However, as this pharmaceutical form is not suitable for infants and young children, a pediatric syrup formulation of FACA ${ }^{\circledR}$ suitable for children under 5 years has just been developed. Standardization and quality control tests were carried out on this formulation 12,13 . However, the efficacy and safety of this new formulation has not yet been evaluated. The objective of this study was, therefore, to assess the acute and subacute oral toxicity and to verify the pharmacological efficacy of this formulation for it use in the management of sickle cell disease.

\section{MATERIALS AND METHODS}

\section{Test article}

The test article was FACA ${ }^{\circledR}$ syrup, a herbal dry syrup made from a mixture of the roots bark powders from Zanthoxylum zanthoxyloides Lam and Calotropis procera Ait. This herbal drug was obtained from the Phytomedicine Production Unit (U-PHARMA) of the "Institut de Recherche en Sciences de la Santé (IRSS)", Ouagadougou, Burkina Faso.

\section{Animals and treatment}

Healthy Adult Wistar rats of both sexes (males and females) weighed between (156 to $197 \mathrm{~g}$ ) were used for the assessment of oral acute and subacute toxicity. The females were nulliparous and not pregnant. The animals were procured from the IRSS pet Shop, Ouagadougou, Burkina Faso. They were housed in the animal cages with free access to water, and standard granula feeds for rat enriched with protein $(29 \%)$. The animals were kept in a room maintained at a temperature of $23^{\circ} \mathrm{C} \pm 3^{\circ} \mathrm{C}$ and a relative humidity of $40 \%$ - 65\% with 12 hours light and 12 hours dark cycle. Animals were randomly selected, marked for individual identification, assigned per group in animals cages and acclimatized to housing conditions during one week before the start of treatment. The experimental protocol was carried out in accordance with international standard protocols [Guidelines set by the European Union on the protection of animals (CEC Council 86/609)] and adopted by IRSS, Burkina Faso.

\section{Acute oral toxicity}

Acute oral toxicity was evaluated according to the Organization for Economic Co-operation and Development (OECD) test guideline 423, the acute toxic class method 14 . Briefly, after fastening period of 4 hours, the rats were weighed and FACA $^{\circledR}$ syrup was administered orally by gavage in a single dose to the animal according to the sequential procedure. In the present study, the starting dose chosen was $2000 \mathrm{mg} / \mathrm{kg}$ b.w. of the test article. After 2 hours of post-treatment observation of all animals, feeding was restored. Animals were then observed at least once daily for 14 days to detect any signs of toxicity such as behavioural or physiological changes and mortality.

\section{Subacute toxicity}

The sub-acute oral toxicity study was performed following the protocol described by the OECD 407 Guideline with minor modification ${ }^{15}$. Forty (40) Wistar rats of both sexes were randomly selected for this study. The females were nulliparous and nonpregnant. The rats were divided into four groups of 10 animals each ( 5 males and 5 females); males and females were kept separately in polypropylene cages.

Group I served as the control received the vehicle (distilled water) and while rats in groups 2, 3 and 4 were respectively received daily doses of 250,500 and $1000 \mathrm{mg} / \mathrm{kg}$ of FACA ${ }^{\circledR}$ syrup. Vehicle and FACA $^{\circledR}$ syrup were administered by gavage each morning at the same time for 28 consecutive days.

Water consumption were monitored daily throughout the study period. Body weight and food consumption were recorded once weekly. On the 29th day of the study, after overnight fasting, all animals were anaesthetized using ketamine. Blood samples of each animal were collected via cardiac puncture into two vacutainers. The first vacutainer containing EDTA was used for haematological assay and the second, a dry vacutainer were used for serum biochemical assays. After blood collection, the vital organs such as heart, kidneys, liver, lung and spleen were isolated and observed macroscopically for any lesions. After that, all organs were dried using toilet paper and weighed on a sensitive balance (Sartorius; precision $0.1 \mathrm{mg}$ ). The relative organ weight ratio (ROW) of each rat was then calculated as follows:

Relative organ weight $(\%)=\frac{\text { absolute weight of organe }(g)}{\text { body weight of animal }(g)} X 100$

\section{Haematological and biochemical analysis}

The whole blood with EDTA as was used for haematology analysis. The following parameters were measured: red blood cell count (RBC), white blood cell count (WBC), haemoglobin (HGB), haematocrit (HCT), blood platelet number (PLT), plateletcrit (PCT), mean corpuscular volume (MCV), mean corpuscular haemoglobin $(\mathrm{MCH})$, mean corpuscular haemoglobin concentration (MCHC), mean platelet volume (MPV), Platelet Distribution Width (PDW) by using a semiautomatic cell counter (Hospitex Diagnostic, model: Hema screen 13, Italy).

The blood samples collected in dry vacutainers were centrifuged at $3000 \mathrm{rpm}$ for $10 \mathrm{~min}$ using a table centrifuge (ROTOFIX 32A, Mettich Zenfrifugen, Germany); the sera obtained were used for biochemical assays. Blood chemicals tests were carried out using an automatic biochemistry analyzer (Mindray BS-300, China). Sera biochemical parameters including total proteins, aspartate aminotransferase, alanine aminotransferase, creatinine and glucose $(\mathrm{mmol} / \mathrm{l})$ were analysis. 


\section{Antisickling activity}

The anti-sickling activity of the extracts was evaluated according to the Emmel test (Emmel, 1933) as described by Seck et al. 16 and Sawadogo et al. ${ }^{17}$. The test was performed in vitro on blood collected from voluntary homozygous $\mathrm{HbS} / \mathrm{HbS}$ SS sickle cell patients in EDTA tubes. After confirmation of their SS status, the collected blood samples were stored at $4{ }^{\circ} \mathrm{C}$ in a refrigerator for a maximum of 8 days before performing the test. In carrying out the test, the blood was diluted in physiological solution ( $\mathrm{NaCl} 9 \%$, an isotonic solution of the cellular medium) at the rate of one volume of blood for two volumes of physiological solution. Different concentrations of FACA ${ }^{\circledR}$ syrup prepared in $\mathrm{NaCl} 9 \%$ were used in the experiment, with Hydrea as a positive control.

Effect of FACA ${ }^{\circledR}$ syrup in curative mode on sickling cells induced by sodium metabisulfite

The effect of FACA ${ }^{\circledR}$ syrup in curative mode on sickling cells induced by sodium metabisulfite was determined following the method described by Seck et al. $18.50 \mu \mathrm{l}$ of blood was mixed with $50 \mu \mathrm{l}$ of $2 \%$ sodium metabisulfite solution (rapid sickling factor) for one hour to induce sickling. Then, this mixture was distributed into different tubes ( $20 \mu \mathrm{l}$ per tube) containing $20 \mu \mathrm{l}$ of FACA ${ }^{\circledR}$ syrup extract at concentrations of $22.2 \mathrm{mg} / \mathrm{ml}$ and $222.2 \mathrm{mg} / \mathrm{ml}$. Hydrea $(10 \mathrm{mg} / \mathrm{ml})$ was used as positive control. The mixture was homogenized and then deposited on a glass slide and covered with a coverslip. Preparation was luted with nail polish and then observed under an optical microscope (X40 objective) every $30 \mathrm{~min}$ up to $120 \mathrm{~min}$.

\section{Effect of FACA ${ }^{\circledR}$ syrup in preventive mode on sickling} cells in the presence of $2 \%$ sodium metabisulfite

The effect of FACA ${ }^{\circledR}$ syrup in preventive mode on sickling cells in the presence of $2 \%$ sodium metabisulfite was assessed according to methods described by Sawadogo et al. ${ }^{17}$

$20 \mu \mathrm{l}$ of blood was pre-incubated for one hour with $20 \mu \mathrm{l}$ of FACA $^{\circledR}$ syrup extract at concentrations of $222.2 \mathrm{mg} / \mathrm{ml}$ and $22.2 \mathrm{mg} / \mathrm{ml}$ and Hydrea $(10 \mathrm{mg} / \mathrm{ml}$ ) (a positive control) respectively. This mixture was mounted between slide and coverslip volume to volume with sodium metabisulphite and luted with nail varnish. The slides were observed under an optical microscope (X40 objective) every thirty minutes after preparation for $120 \mathrm{~min}$.

\section{Statistical analysis}

The results obtained were presented as mean \pm standard deviation. Data were calculated separately for males and females using Microsoft Excel 2010 software. Significant differences were determined using one-way analysis of variance (ANOVA) followed by Dunnett's multiple comparison tests. The statistical analyses were done using GraphPad Prism software. 5 (GraphPad Software, San Diego, California, United States). Differences between means of treated groups and the control were considered as statistically significant at $\mathrm{P} \leq 0.05$.

\section{RESULTS}

\section{Acute toxicity study}

In acute oral toxicity study, no death was recorded in the 14 days of the observation period in the animals treated with FACA $^{\circledR}$ syrup extract in a single dose of $2000 \mathrm{mg} / \mathrm{kg} / \mathrm{b} . \mathrm{w}$. Also, the animals did not show any changes in the general appearance during the observation period. According to OECD test guideline 423, the estimate lethal dose $50 \%$ $\left(L_{50}\right)$ of FACA ${ }^{\circledR}$ syrup extract is $5000 \mathrm{mg} / \mathrm{kg} / \mathrm{b} . \mathrm{w}$.

\section{Subacute toxicity study}

In the subacute oral toxicity study, a daily administration of FACA $^{\circledR}$ syrup during 28 days did not result in any behavioural changes in the treated rats compared to the control one. In addition, no mortality was recorded during the study period.

\section{Water consumption}

Table 1 shows the daily water consumption in the control and treated rats. The results in this table show a slight decrease in daily water consumption in rats treated with 500 and $1000 \mathrm{mg} / \mathrm{kg}$ b.w. However, this decrease is not statistically significant $(\mathrm{P}>0,05)$.

Table 1: Mean daily water consumption ( $\mathrm{mL} /$ rat / day)

\begin{tabular}{llllll}
\hline \multirow{2}{*}{ Dose (mg/kg b.w.) } & Sex & \multicolumn{3}{c}{ Weeks } \\
\cline { 3 - 5 } & & Week 1 & Week 2 & Week 1 & Week 2 \\
\hline Control & M & $40.29 \pm 5.56$ & $43.86 \pm 2.19$ & $35.43 \pm 2.82$ & $38.00 \pm 5.72$ \\
& F & $49.57 \pm 14.86$ & $46.71 \pm 5.44$ & $40.43 \pm 4.54$ & $41.14 \pm 7.93$ \\
250 & M & $36.43 \pm 7.30$ & $41.00 \pm 3.06$ & $33.71 \pm 4.15$ & $35.29 \pm 3.30$ \\
& F & $39.14 \pm 7.06$ & $41.57 \pm 2.37$ & $34.00 \pm 5.35$ & $37.86 \pm 5.08$ \\
1000 & M & $38.43 \pm 6.00$ & $41.86 \pm 2.41$ & $34.14 \pm 6.15$ & $37.86 \pm 3.80$ \\
& F & $42.86 \pm 9.37$ & $46.29 \pm 6.16$ & $40.57 \pm 6.60$ & $42.14 \pm 10.48$ \\
& M & $42.86 \pm 9.37$ & $46.29 \pm 6.16$ & $40.57 \pm 6.60$ & $42.14 \pm 10.48$ \\
\hline
\end{tabular}

Mean and Standard deviation are presented ( $n=5 / \operatorname{sex}) ; M=$ male ; F = female 


\section{Foods consumption}

Table 2 shows the variations in the mean daily food consumption of the treated and control rats during the treatment period. These results show that daily administration of FACA resulted in a slight increase in food consumption in all rats treated compared to controls.

Table 2: Mean daily food consumption (g/rat/day)

\begin{tabular}{|c|c|c|c|c|c|}
\hline \multirow{2}{*}{ Days } & \multirow{2}{*}{ sex } & \multicolumn{4}{|c|}{ Doses (mg/kg/b.W.) } \\
\hline & & Control & $250 \mathrm{mg} / \mathrm{kg}$ & $500 \mathrm{mg} / \mathrm{kg}$ & $1000 \mathrm{mg} / \mathrm{kg}$ \\
\hline \multirow[t]{2}{*}{ D0-D7 } & $\mathrm{M}$ & 23.80 & 26.20 & 25.40 & 25.54 \\
\hline & $\mathrm{F}$ & 20.03 & 18.57 & 22.11 & 21.91 \\
\hline \multirow[t]{2}{*}{ D7-D14 } & M & 23.11 & 23.43 & 26.71 & 24.23 \\
\hline & $\mathrm{F}$ & 20.23 & 21.51 & 20.71 & 22.06 \\
\hline \multirow[t]{2}{*}{ D14-D21 } & M & 23.49 & 25.46 & 25.14 & 23.17 \\
\hline & $\mathrm{F}$ & 18.31 & 18.06 & 18.77 & 24.57 \\
\hline \multirow[t]{2}{*}{ D21-D28 } & M & 24.60 & 26.69 & 26.17 & 24.49 \\
\hline & $\mathrm{F}$ & 20.37 & 21.43 & 20.43 & 23.09 \\
\hline
\end{tabular}

Mean and Standard deviation are presented $(\mathrm{n}=5 / \mathrm{sex}) ; \mathrm{M}=$ male $; \mathrm{F}=$ female

\section{Variation in body weight}

The variations in body weight of the control rats and those treated daily with FACA ${ }^{\circledR}$ syrup for 28 days are presented in figure 1 and 2 respectively for the males and the females. These figures show an increase in weight in all the rats during the treatment period. Statistical analysis of these results shows that there is no significant difference in weight between the treated male rats compared to the controls. However, in females treated with $250 \mathrm{mg} / \mathrm{kg}$ there is a significant decrease in weight gain during the fourth week of treatment $(\mathrm{p}<0,01)$.

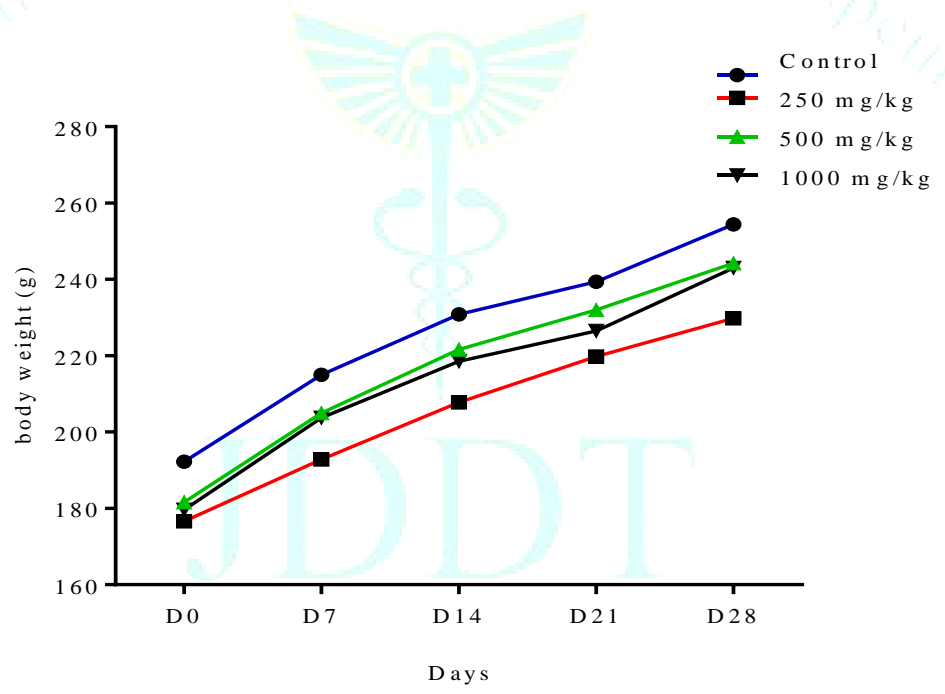

Figure 1: Mean body weight variation in control and treated male rats $(n=5)$

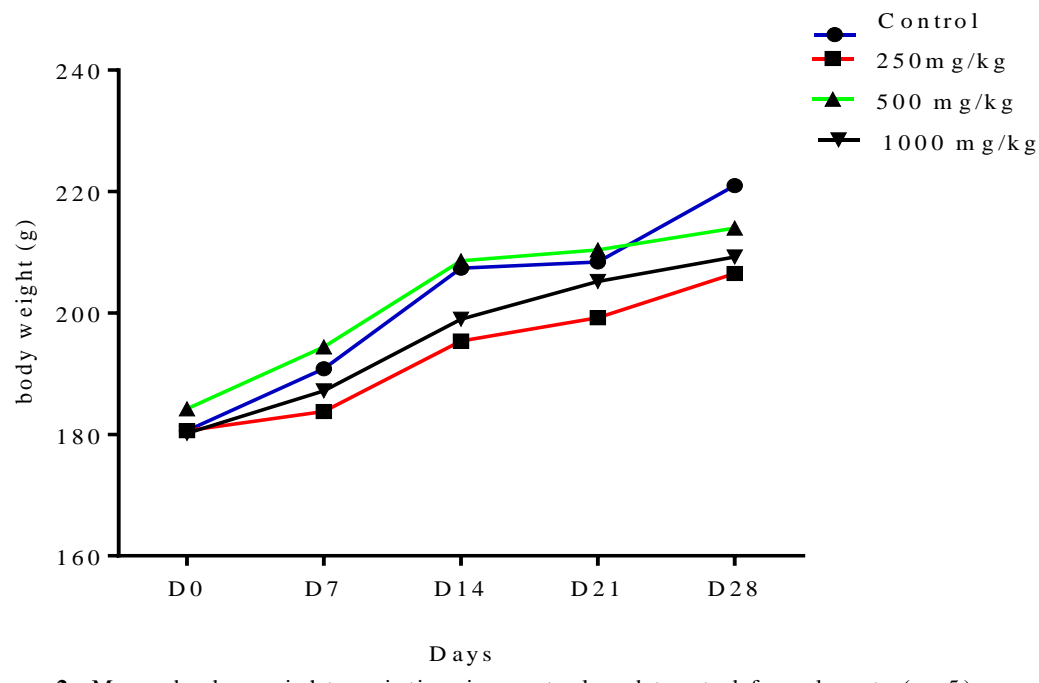

Figure 2: Mean body weight variation in control and treated female rats $(n=5)$ 


\section{Relative organ weight of rats}

The relative organ weights (\%) of both Rats and those treated daily with FACA ${ }^{\circledR}$ syrup for 28 days is presented in table 4. Statistical analysis of these results revealed no significant difference in relative weight between the organs of the treated rats and those of the control rats $(\mathrm{P}>0,05)$.

Table 4: Relative organ weight of rats (males and females) after a 28 day treatment with FACA ${ }^{\circledR}$ syrup

\begin{tabular}{|c|c|c|c|c|c|c|c|}
\hline \multirow{2}{*}{$\begin{array}{l}\text { Doses } \\
\text { (mg/kg/b.w.) }\end{array}$} & \multirow{2}{*}{ Sex } & \multicolumn{6}{|c|}{ Organs (\% b.w.) } \\
\hline & & Foie & Reins & Cœur & Poumons & Rate & Estomac \\
\hline \multirow{2}{*}{ Control } & $\mathrm{M}$ & $2.61 \pm 0.17$ & $0.66 \pm 0.06$ & $0.30 \pm 0.03$ & $0.47 \pm 0.05$ & $0.21 \pm 0.01$ & $1.09 \pm 0.14$ \\
\hline & $\mathrm{F}$ & $2.77 \pm 0.18$ & $0.64 \pm 0.05$ & $0.32 \pm 0.03$ & $0.57 \pm 0.11$ & $0.23 \pm 0.04$ & $1.08 \pm 0.13$ \\
\hline \multirow{2}{*}{250} & $\mathrm{M}$ & $2.68 \pm 0.15$ & $0.69 \pm 0.07$ & $0.31 \pm 0.03$ & $0.49 \pm 0.06$ & $0.21 \pm 0.04$ & $0.89 \pm 0.05$ \\
\hline & $\mathrm{F}$ & $2.74 \pm 0.03$ & $0.62 \pm 0.04$ & $0.32 \pm 0.04$ & $0.49 \pm 0.07$ & $0.25 \pm 0.03$ & $1.07 \pm 0.13$ \\
\hline \multirow{2}{*}{500} & $\mathrm{M}$ & $2.47 \pm 0.16$ & $0.63 \pm 0.04$ & $0.34 \pm 0.04$ & $0.44 \pm 0.15$ & $0.19 \pm 0.02$ & $0.89 \pm 0.10$ \\
\hline & $\mathrm{F}$ & $2.82 \pm 0.11$ & $0.63 \pm 0.04$ & $0.33 \pm 0.02$ & $0.54 \pm 0.06$ & $0.24 \pm 0.03$ & $1.11 \pm 0.16$ \\
\hline \multirow{2}{*}{1000} & M & $2.45 \pm 0.15$ & $0.63 \pm 0.06$ & $0.33 \pm 0.02$ & $0.42 \pm 0.03$ & $0.21 \pm 0.03$ & $1.08 \pm 0.30$ \\
\hline & $\mathrm{F}$ & $2.65 \pm 0.15$ & $0.62 \pm 0.05$ & $0.31 \pm 0.03$ & $0.48 \pm 0.06$ & $0.22 \pm 0.02$ & $1.14 \pm 0.47$ \\
\hline
\end{tabular}

Mean and Standard deviation are presented $(n=5 / \operatorname{sex}) ; M=$ male ; F = female

\section{Effect of FACA ${ }^{\circledR}$ syrup on haematological parameters}

The results of the analysis of the haematological parameters of the blood of the control rats and those treated daily with the doses of 250,500 , and $1000 \mathrm{mg} / \mathrm{kg}$ of FACA ${ }^{\circledR}$ syrup for 28 days are summarized in Table 5. As shown in this table, daily administration of FACA ${ }^{\circledR}$ syrup to rats did not result in a major change in hematological profile when compared to control rat. Statistical analysis of the results did not reveal any significant difference in hematological parameters of rats treated with FACA $^{\circledR}$ syrup compared to the control rats $(\mathrm{P}>0.05)$.

Table 5: Effect of daily administration of FACA ${ }^{\circledR}$ syrup for 28 days on hematological profiles of the control and treated rats

\begin{tabular}{|c|c|c|c|c|c|}
\hline \multirow{2}{*}{ Parameters } & \multirow{2}{*}{ Sex } & \multicolumn{4}{|c|}{ Doses (mg/kg/b.w) } \\
\hline & & Control & $250 \mathrm{mg} / \mathrm{kg}$ & $500 \mathrm{mg} / \mathrm{kg}$ & $1000 \mathrm{mg} / \mathrm{kg}$ \\
\hline \multirow[t]{2}{*}{$\mathrm{WBC} * 103 / \mu \mathrm{L}$} & $\mathrm{M}$ & $5.35 \pm 2.58$ & $7.46 \pm 3.41$ & $6.12 \pm 1.28$ & $5.74 \pm 2.81$ \\
\hline & $\mathrm{F}$ & $5.44 \pm 1.11$ & $7.14 \pm 2.04$ & $5.78 \pm 0.68$ & $6.12 \pm 1.36$ \\
\hline \multirow[t]{2}{*}{$\mathrm{RBC}^{*} 10^{6} / \mu \mathrm{L}$} & M & $6.38 \pm 0.22$ & $6.25 \pm 0.27$ & $6.21 \pm 0.38$ & $6.20 \pm 0.34$ \\
\hline & $\mathrm{F}$ & $5.83 \pm 0.26$ & $5.65 \pm 0.38$ & $5.87 \pm 0.45$ & $5.69 \pm 0.20$ \\
\hline \multirow[t]{2}{*}{ HGB (g/dL) } & M & $14.50 \pm 6.98$ & $14.28 \pm 4.27$ & $14.13 \pm 5.32$ & $14.13 \pm 8.62$ \\
\hline & $\mathrm{F}$ & $13.00 \pm 6.37$ & $13.50 \pm 7.53$ & $12.90 \pm 4.24$ & $13.25 \pm 3.42$ \\
\hline \multirow[t]{2}{*}{ НСТ (\%) } & M & $35.85 \pm 2.52$ & $36.19 \pm 1.06$ & $35.04 \pm 1.81$ & $35.20 \pm 1.92$ \\
\hline & $\mathrm{F}$ & $34.09 \pm 2.24$ & $33.27 \pm 1.91$ & $34.12 \pm 2.44$ & $33.44 \pm 0.58$ \\
\hline \multirow[t]{2}{*}{$\operatorname{MCV}(f)$} & M & $54.60 \pm 2.61$ & $56.20 \pm 1.10$ & $54.80 \pm 1.79$ & $55.20 \pm 1.64$ \\
\hline & $\mathrm{F}$ & $56.80 \pm 1.30$ & $57.00 \pm 1.58$ & $57.60 \pm 2.51$ & $57.20 \pm 1.30$ \\
\hline \multirow[t]{2}{*}{ MCH (pg) } & M & $22.37 \pm 0.84$ & $22.68 \pm 0.21$ & $22.41 \pm 0.98$ & $22.44 \pm 0.83$ \\
\hline & $\mathrm{F}$ & $23.06 \pm 0.85$ & $23.73 \pm 0.72$ & $23.59 \pm 0.87$ & $23.25 \pm 0.39$ \\
\hline \multirow[t]{2}{*}{ MCHC (g/dL) } & M & $40.60 \pm 9.82$ & $39.88 \pm 6.06$ & $40.42 \pm 14.15$ & $40.26 \pm 6.19$ \\
\hline & $\mathrm{F}$ & $40.22 \pm 9.42$ & $41.04 \pm 7.67$ & $40.46 \pm 5.03$ & $40.28 \pm 6.94$ \\
\hline \multirow[t]{2}{*}{ RDWCV(\%) } & M & $16.80 \pm 2.17$ & $15.20 \pm 0.84$ & $16.20 \pm 1.64$ & $15.40 \pm 2.07$ \\
\hline & $\mathrm{F}$ & $14.60 \pm 0.55$ & $14.40 \pm 1.14$ & $14.60 \pm 1.52$ & $14.00 \pm 1.58$ \\
\hline \multirow[t]{2}{*}{ RDWSD (fL) } & M & $85.33 \pm 1.39$ & $83.83 \pm 0.45$ & $84.99 \pm 1.32$ & $84.16 \pm 1.02$ \\
\hline & $\mathrm{F}$ & $83.00 \pm 0.45$ & $82.83 \pm 0.75$ & $82.50 \pm 1.56$ & $82.33 \pm 0.91$ \\
\hline \multirow[t]{2}{*}{$\mathrm{PLT}^{*} 10^{6} / \mu \mathrm{L}$} & M & $515.00 \pm 32.23$ & $495.00 \pm 17.90$ & $494.80 \pm 36.47$ & $500.00 \pm 31.92$ \\
\hline & $\mathrm{F}$ & $594.80 \pm 44.73$ & $584.00 \pm 51.57$ & $552.60 \pm 63.14$ & $573.40 \pm 49.55$ \\
\hline \multirow[t]{2}{*}{ MPV (fL) } & M & $9.61 \pm 0.32$ & $9.58 \pm 0.41$ & $9.92 \pm 0.79$ & $9.75 \pm 0.36$ \\
\hline & $\mathrm{F}$ & $9.36 \pm 0.35$ & $9.11 \pm 0.13$ & $9.21 \pm 0.39$ & $9.23 \pm 0.31$ \\
\hline \multirow[t]{2}{*}{ PDW (fL) } & M & $14.80 \pm 0.14$ & $14.80 \pm 0.14$ & $15.04 \pm 0.59$ & $14.90 \pm 0.30$ \\
\hline & $\mathrm{F}$ & $14.72 \pm 0.11$ & $14.64 \pm 0.09$ & $14.80 \pm 0.24$ & $14.68 \pm 0.11$ \\
\hline \multirow[t]{2}{*}{ РCT (\%) } & M & $0.49 \pm 0.03$ & $0.47 \pm 0.03$ & $0.48 \pm 0.01$ & $0.50 \pm 0.06$ \\
\hline & $\mathrm{F}$ & $0.54 \pm 0.04$ & $0.52 \pm 0.04$ & $0.50 \pm 0.05$ & $0.52 \pm 0.03$ \\
\hline
\end{tabular}

Mean and Standard deviation are presented ( $\mathrm{n}=5 / \mathrm{sex}) ; \mathrm{M}=$ male $; \mathrm{F}=$ female 


\section{Effect of FACA ${ }^{\circledR}$ syrup on biochemical parameters}

Daily administration of FACA $®$ syrup to rats for 28 days resulted in a slight increase of blood creatinine, total protein and AST levels in all rats treated compared to controls. There is also an increase in blood glucose in all the treated males and in the females treated with $1000 \mathrm{mg} / \mathrm{kg}$ b.w. On the other hand, there is a decrease in the ALAT level in all the treated rats and in the cholesterol level only in females treated. P042- and $\mathrm{Ca}^{2+}$ levels increased in all treated females while in treated males, these two parameters decreased compared to control rats. The statistical analysis of these results (Table 6) shows that all these variations in the rates of biochemical parameters were not statistically significant $(\mathrm{p}>0.005)$.

Table 6: Effect of daily administration of FACA $^{\circledR}$ syrup for 28 days on biochemical profiles of the control and treated rats

\begin{tabular}{|c|c|c|c|c|c|}
\hline \multirow{2}{*}{ Parameters } & \multirow{2}{*}{ sex } & \multicolumn{4}{|c|}{ Dose (mg/kg/b.w.) } \\
\hline & & Control & $250 \mathrm{mg} / \mathrm{kg}$ & $500 \mathrm{mg} / \mathrm{kg}$ & $1000 \mathrm{mg} / \mathrm{kg}$ \\
\hline \multirow[t]{2}{*}{ Glucose (mmol/L) } & $\mathrm{M}$ & $2.97 \pm 0.91$ & $2.99 \pm 0.78$ & $3.43 \pm 0.74$ & $3.75 \pm 0.79$ \\
\hline & $\mathrm{F}$ & $3.23 \pm 0.56$ & $3.08 \pm 0.61$ & $3.16 \pm 0.66$ & $3.99 \pm 0.30$ \\
\hline \multirow[t]{2}{*}{ Creatinine $(\mu \mathrm{mol} / \mathrm{L})$} & M & $54.06 \pm 6.68$ & $60.52 \pm 10.56$ & $59.26 \pm 6.86$ & $61.70 \pm 5.80$ \\
\hline & $\mathrm{F}$ & $55.50 \pm 3.82$ & $61.40 \pm 11.44$ & $57.72 \pm 7.62$ & $65.40 \pm 6.38$ \\
\hline \multirow[t]{2}{*}{ Total Cholesterol (mmol/L) } & M & $1.38 \pm 0.36$ & $1.44 \pm 0.58$ & $1.38 \pm 0.34$ & $1.38 \pm 0.09$ \\
\hline & $\mathrm{F}$ & $1.62 \pm 0.35$ & $1.32 \pm 0.26$ & $1.39 \pm 0.26$ & $1.35 \pm 0.31$ \\
\hline \multirow[t]{2}{*}{ Total Proteines (g/L) } & M & $52.14 \pm 5.18$ & $58.26 \pm 2.81$ & $56.34 \pm 5.27$ & $55.43 \pm 1.94$ \\
\hline & $\mathrm{F}$ & $57.20 \pm 8.98$ & $58.60 \pm 6.91$ & $60.76 \pm 5.36$ & $62.86 \pm 3.61$ \\
\hline \multirow[t]{2}{*}{ ASAT (UI/L) } & M & $113.40 \pm 19.77$ & $134.00 \pm 21.76$ & $122.20 \pm 10.31$ & $113.40 \pm 14.12$ \\
\hline & $\mathrm{F}$ & $116.00 \pm 20.10$ & $119.40 \pm 21.09$ & $119.80 \pm 29.51$ & $154.60 \pm 29.64$ \\
\hline \multirow[t]{2}{*}{ ALAT (UI/L) } & M & $63.80 \pm 12.76$ & $62.40 \pm 5.68$ & $61.20 \pm 19.83$ & $44.00 \pm 3.39$ \\
\hline & $\mathrm{F}$ & $72.40 \pm 16.41$ & $66.40 \pm 5.13$ & $54.00 \pm 11.45$ & $69.20 \pm 15.51$ \\
\hline \multirow[t]{2}{*}{$\mathrm{Cl}^{-}(\mathrm{mmol} / \mathrm{L})$} & M & $107.60 \pm 3.05$ & $108.40 \pm 3.36$ & $107.40 \pm 3.85$ & $109.60 \pm 2.41$ \\
\hline & $\mathrm{F}$ & $106.60 \pm 6.88$ & $104.00 \pm 6.67$ & $107.40 \pm 1.82$ & $102.40 \pm 6.43$ \\
\hline \multirow[t]{2}{*}{ P042- $(\mathbf{m m o l} / \mathrm{L})$} & M & $3.42 \pm 0.46$ & $3.26 \pm 0.29$ & $3.28 \pm 0.55$ & $2.99 \pm 0.10$ \\
\hline & $\mathrm{F}$ & $2.63 \pm 0.25$ & $3.14 \pm 0.37$ & $3.08 \pm 0.52$ & $2.81 \pm 0.49$ \\
\hline \multirow[t]{2}{*}{$\mathrm{Ca}^{2+}(\mathrm{mmol} / \mathrm{L})$} & M & $2.78 \pm 0.24$ & $2.59 \pm 0.38$ & $2.56 \pm 0.16$ & $2.75 \pm 0.16$ \\
\hline & $\mathrm{F}$ & $2.54 \pm 0.29$ & $2.63 \pm 0.32$ & $2.60 \pm 0.33$ & $2.94 \pm 0.32$ \\
\hline \multirow[t]{2}{*}{$\mathrm{Na}^{+}(\mathrm{mmol} / \mathrm{L})$} & M & $135.20 \pm 5.41$ & $135.60 \pm 6.24$ & $142.30 \pm 8.70$ & $136.60 \pm 3.70$ \\
\hline & $\mathrm{F}$ & $136.00 \pm 7.88$ & $134.50 \pm 4.03$ & $135.00 \pm 4.18$ & $137.00 \pm 5.72$ \\
\hline \multirow[t]{2}{*}{$\mathrm{K}^{+}(\mathrm{mmol} / \mathrm{L})$} & M & $7.02 \pm 1.13$ & $6.55 \pm 1.66$ & $5.30 \pm 0.52$ & $5.45 \pm 0.54$ \\
\hline & $\mathrm{F}$ & $5.68 \pm 1.15$ & $5.64 \pm 0.75$ & $5.78 \pm 0.76$ & $5.18 \pm 0.75$ \\
\hline
\end{tabular}




\section{Anti-sickling activity}

\section{Effect of FACA ${ }^{\circledR}$ syrup in curative mode on sickling induced} by sodium metabisulfite.

Figure 1 illustrates the anti-sickling activities of FACA ${ }^{\circledR}$ syrup extracts and Hydrea on sodium metabisulfite-induced sickling of red blood cells. As shown in this figure the extract, at $22.2 \mathrm{mg} / \mathrm{ml}$ (picture b) and at $222.2 \mathrm{mg} / \mathrm{ml}$ (picture c) has a potential to normalize drepanocytes (passage of red blood cells from sickle shape to normal) compared to negative controls (untreated cells) (picture a). This anti-sickling activity was comparable to that of Hydrea $10 \mathrm{mg} / \mathrm{ml}$ (pictured), used as a positive control.
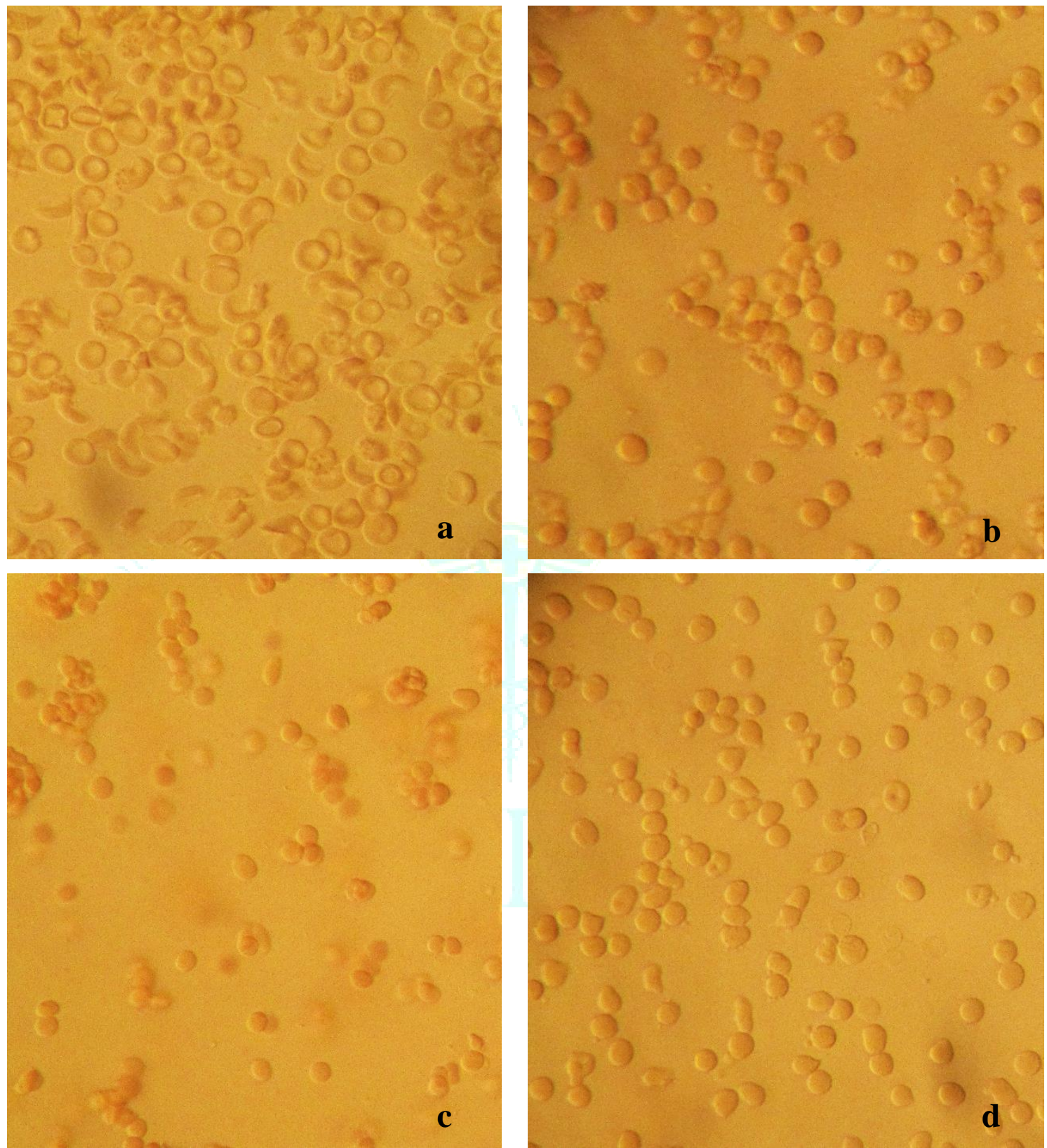

Figure 1 : : Morphology of drepanocytes induced by sodium metabisulfite then treated with FACA ${ }^{\circledR}$ syrup extract or Hydrea

a-phenotype of SS erythrocytes in the presence of sodium metabisulfite $(20 \mathrm{mg} / \mathrm{ml})$ only for 1 hour

b- phenotype of SS erythrocytes treated with sodium metabisulfite (1 hour), then with extract ( $22.2 \mathrm{mg} / \mathrm{ml})$ for 30 minutes

c- phenotype of SS erythrocytes treated with sodium metabisulfite (1 hour), then with extract ( $222.2 \mathrm{mg} / \mathrm{ml})$ for $30 \mathrm{minutes}$

d- phenotype of SS erythrocytes treated with sodium metabisulfite ( 1 hour), then with Hydrea ( $10 \mathrm{mg} / \mathrm{ml})$ for 30 minutes 


\section{Effect of FACA ${ }^{\circledR}$ syrup in preventive mode on sickling in the presence of $2 \%$ sodium metabisulfite}

Figures 2 and 3 show the morphology of untreated SS sickle cells (negative controls), in the presence of extract or of Hydrea and 2\% sodium metabisulfite. Morphological analysis of these images shows that the extract at a concentration of $22.2 \mathrm{mg} / \mathrm{ml}$ and $222.2 \mathrm{mg} / \mathrm{ml}$ has greater antifalcemic activity than Hydrea. Indeed, figure 2 shows red blood cells of normal appearance in the presence of the extract at 22.2 $\mathrm{mg} / \mathrm{ml}$ (figure 2.b) and at $222.2 \mathrm{mg} / \mathrm{ml}$ (figure 2.c) and metabisulfite sodium 1 hour later. Figure 3 shows the morphology of the erythrocytes in the presence of the extractor of the hydrea and of sodium metabisulfite for 2 hours. This figure shows the appearance of sickle cells in the presence of sodium metabisulite and of the extract at 22.2 $\mathrm{mg} / \mathrm{ml}$ (Figure 3.b) and $222.2 \mathrm{mg} / \mathrm{ml}$ (Figure 3.c). Figures 2.d and 3.d show sickled red blood cells in the presence of hydrea and sodium metabisulfite. Hydra, unlike the extract, is not able to inhibit the red blood cell sickle induced by sodium metabisulfite 1 hour later.
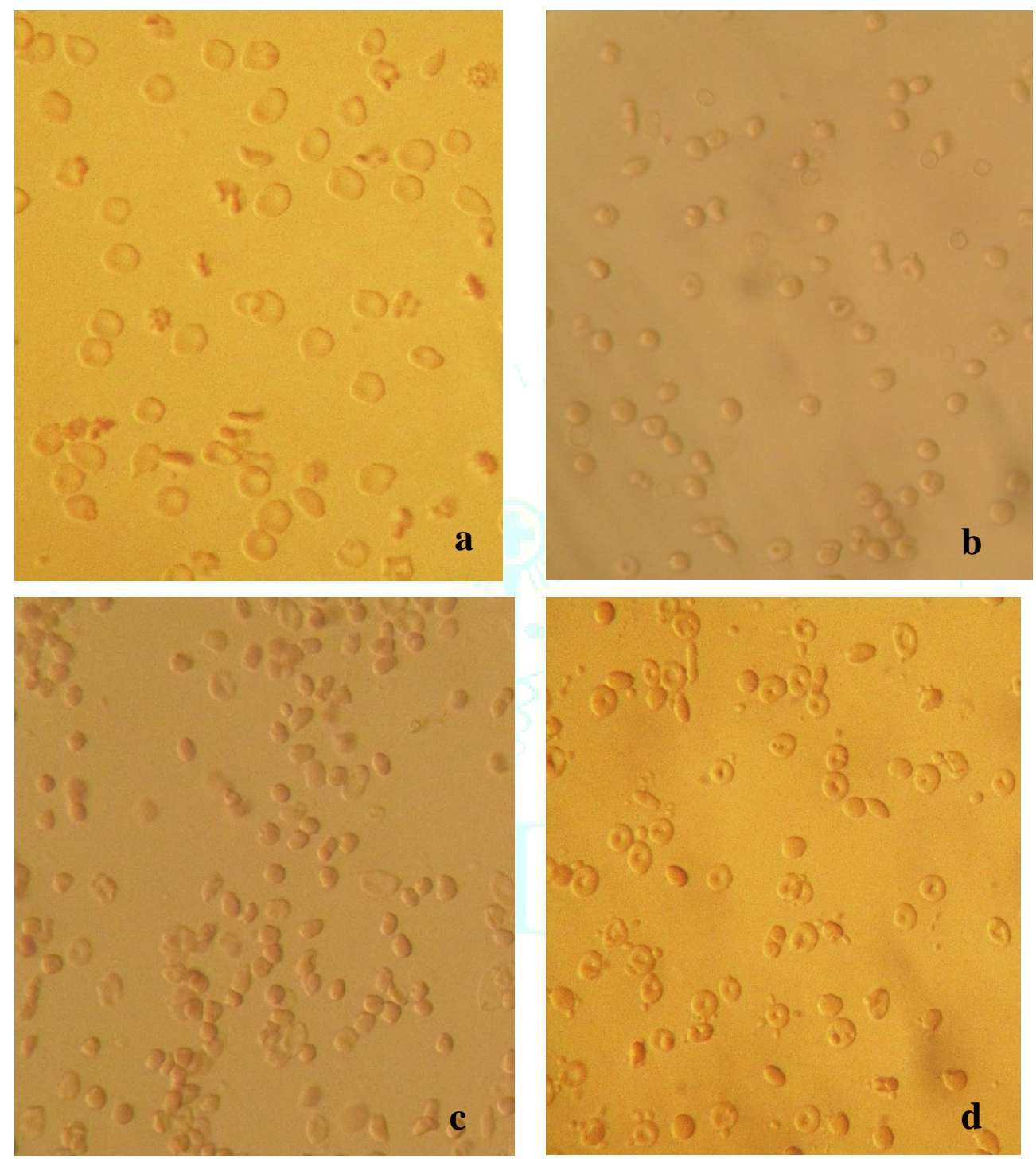

Figure 2: morphology of SS erythrocytes in the presence of extract or hydrea and sodium metabisulfite for 1 hour.

a- Phenotype of untreated SS erythrocytes

b- phenotypes of SS erythrocytes treated with the extract at $22.2 \mathrm{mg} / \mathrm{ml}$ (1 hour) then with sodium metabisulfite for 1 hour. c- phenotypes of SS erythrocytes treated with extract at $222.2 \mathrm{mg} / \mathrm{ml}$ (1 hour) then with sodium metabisulfite for 1 hour. d- phenotypes of SS erythrocytes treated with hydrea at $10 \mathrm{mg} / \mathrm{ml}$ (1 hour) then with sodium metabisulfite for 1 hour. 

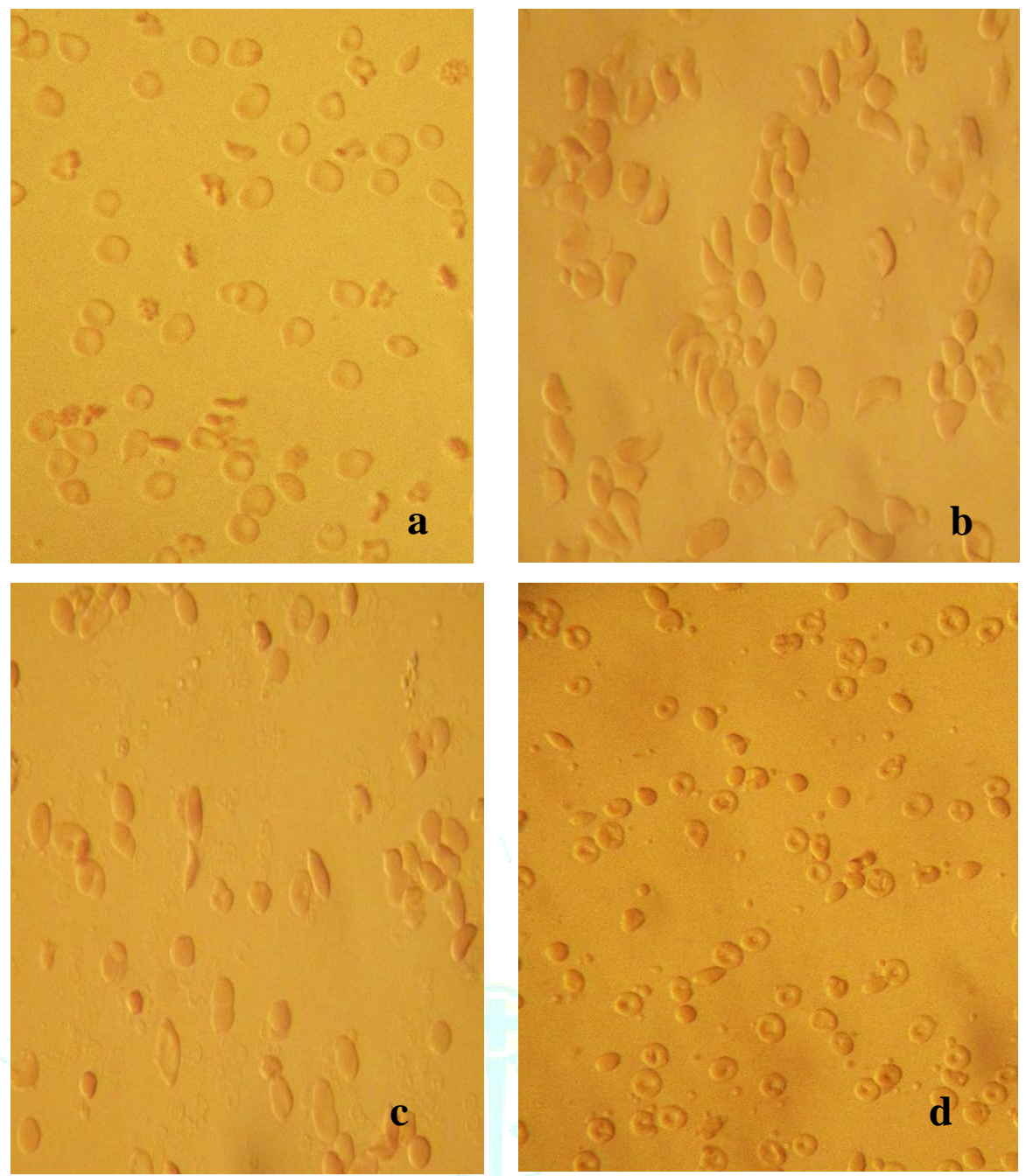

Figure 3: morphology of SS erythrocytes in the presence of extract or hydrea and sodium metabisulphite for 2 hours.

a- Phenotype of untreated SS erythrocytes

b- phenotypes of SS erythrocytes treated with the extract at $22.2 \mathrm{mg} / \mathrm{mL}(1 \mathrm{~h}$ ) then with sodium metabisulfite for $2 \mathrm{~h}$.

c- phenotypes of SS erythrocytes treated with the extract at $222.2 \mathrm{mg} / \mathrm{mL}$ (1 hour) and then with sodium metabisulfite for 2 hours.

d- phenotypes of SS erythrocytes treated with hydrea at $10 \mathrm{mg} / \mathrm{mL}(1 \mathrm{~h})$ then with sodium metabisulphite for $2 \mathrm{~h}$.

\section{DISCUSSION}

FACA $^{\circledR}$ syrup is a phytomedicine developed by IRSS, Burkina Faso for treatment of sickle cell crises. It is formulated based on two medicinal plants both widely used in Burkina Faso against a variety of diseases including sickle cell disease. Although a long history of traditional use may suggest evidence of the safety of herbal medicine/products, some studies revealed the association between herbal medicine and adverse health effects. To provide data on the safety and toxicological profile of FACA ${ }^{\circledR}$ syrup, this study aimed to assess the acute and subacute toxicity of the phytomedicine in Wistar Rat. As herbal medicine toxicity could be related to extrinsic or intrinsic factors, physico-chemical, pharmacotechnical and microbiological control studies of FACA ${ }^{\circledR}$ syrup and its vegetable raw materials studies have been previously conducted, with results indicating absence of chemical and biological contaminants in this herbal-based medicinal product $^{12}$. It is in order to highlight the potential intrinsic toxicity of standardized "FACA ${ }^{\circledR}$ syrup" that toxicological studies were undertaken in this work.

When acute toxicity was investigated, the results showed no signs of toxicity such as general behaviour change, mortality, or change in the macroscopic appearance of internal organs at a single dose of $2000 \mathrm{mg} / \mathrm{kg}$ b.w. in Wistar Rat. Based on the absence of mortality in test animals and in accordance with OECD guideline $423(14)$, the phytomedicament FACA ${ }^{\circledR}$ syrup has an estimated lethal dose $50 \%\left(L_{50}\right)$ of 5000 $\mathrm{mg} / \mathrm{kg}$ b.w. With such $\mathrm{LD}_{50}$, "FACA ${ }^{\circledR}$ syrup is classified as practically non-toxic compound ${ }^{19}$. This result is consistent with that of the acute toxicity study of FACA ${ }^{\circledR}$ capsule with an estimated $\mathrm{LD}_{50}$ of $5000 \mathrm{mg} / \mathrm{kg}$ bw in NMRI mice ${ }^{10}$. Furthermore, previous studies have shown that the parts of both plants used in the formulation of FACA ${ }^{\circledR}$ syrup are practically non-toxic. In mice, the oral $\mathrm{LD}_{50}$ of the methanolic extract of Z. zanthoxyloides (ex Fagara zanthoxyloides) was found to be $5000 \mathrm{mg} / \mathrm{kg}$ b.w.20. No mortality or external toxicity sign was observed after oral administration of $C$. procera root barks extracts at the dose of $3000 \mathrm{mg} / \mathrm{kg}$ b.w. in the rat 21. An acute toxicity study on aqueous and hydroalcoholic extracts of $C$. procera root bark yielded an oral $\mathrm{LD}_{50}$ greater than $2000 \mathrm{mg} / \mathrm{kg}$ in NMRI mice ${ }^{22}$. In addition, the aqueous extract of the plant does not present major toxic effects on the cardiovascular system in vivo ${ }^{23}$.

In addition to acute toxicity, the present study focused on subacute toxicity of FACA ${ }^{\circledR}$ syrup. After four weeks daily oral administration of test product at doses of 250, 500 and 
$1000 \mathrm{mg} / \mathrm{kg}$ b.w., the results revealed no mortality or noticeable behavioral change in the treated groups of rats, compared to control group one. However, the results show a slight non-significant decrease in daily water consumption in rats treated with 500 and $1000 \mathrm{mg} / \mathrm{kg} \mathrm{b.w.} \mathrm{and} \mathrm{a} \mathrm{slight}$ increase in food consumption in all treated rats. Irrespective to female rats treated with the dose of $250 \mathrm{mg} / \mathrm{kg}$ b.w. of FACA ${ }^{\circledR}$ syrup, no significant difference was found in weight between the treated male rats compared to the controls. In female rats treated with extract at $250 \mathrm{mg} / \mathrm{kg} \mathrm{b.w.,} \mathrm{there} \mathrm{has}$ been a significant decline in body weight gain during the fourth week of treatment $(p<0,01)$. Several authors agree that changes in weight of animals in a toxicity test are a reliable endpoint for assessing the effect of toxic substances on the body 24,25 ( Betti et al., 2012 ; Banerjee et al., 2013). According to Pariyani et al 26 , monitoring the body weight and food/water consumption of laboratory animals during toxicity and safety studies of the chemical provides information on the physiological and metabolic state of the animals and avoids misinterpretations related to nutritional abnormalities of the animals during the test. At the doses of 100,200 and $400 \mathrm{mg} / \mathrm{kg}$ b.w., Kinda et al. ${ }^{21}$ shown that $C$. procera root bark aqueous extract provoked a light but nonsignificant decrease of animal's body weight in all treated groups. Following the oral administration of the methanolic extract of stem bark of $Z$. zanthoxyloides up to the dose of 3.0 $\mathrm{mg} / \mathrm{kg}$ b.w. for 21 days, animals of all the groups have depicted an increase in the body weight 27 .

The organ as heart, liver, lung, kidney, spleen, and stomach examination revealed no noticeable change in their macroscopic aspects. With respect to relative organs weight, no significant difference was observed between treated animals and control ones $(\mathrm{P}>0,05)$. Similar to the results of the current study, neither the methanolic extract of $Z$. zanthoxyloides stem barks up to the dose of $3 \mathrm{mg} / \mathrm{kg}$ b.w. for 21 days 27 nor the aqueous extract of $C$. procera root barks up to the dose of $400 \mathrm{mg} / \mathrm{kg}$ b.w. for 28 days 21 was responsible for any change in the appearance of relative organs weight of the treated rats respectively. These results suggest the tolerance of the organs to FACA $^{\circledR}$ syrup. Interestingly, this tolerance seems to be confirmed by the results of the blood biochemical analyses. Indeed, the daily oral administration of FACA ${ }^{\circledR}$ syrup to rats for 28 days did not alter the blood biochemical parameters of the treated rats as they remained close to those of the control animals. Hematological parameters are as important as biochemical parameters in the assessment of a product's toxicity. Furthermore, as a drug used in the treatment of sickle cell disease, monitoring of hematological parameters is of particular importance. In the same way of biochemical results, there was no significant change in haematological parameters. Although there was a very slight reduction of parameters such as the red blood cells (RBC), the hemoglobin (HGB), the PLT, the MCHC, and the PCT levels, no statistically significant difference $(p>0.05)$ was found between the values of treated and control rats. This indicates that FACA $^{\circledR}$ syrup is safe to use with respect to the parameters under consideration. These findings are consistent with those of the FACA ${ }^{\circledR}$ capsule form. Indeed, FACA ${ }^{\circledR}$ capsule did not cause significant changes in biological parameters under clinical monitoring, nor hemolysis of the red blood cells under experimental conditions up to a concentration of $2.5 \mathrm{mg} / \mathrm{mL}$ in vitro 28 . In addition, the aqueous extract of $C$. procera root bark, up to a concentration of $20 \%$, did not cause hemolysis on red blood cells in an isotonic medium ${ }^{29}$.

To verify the pharmacological efficacy of FACA ${ }^{\circledR}$ syrup for the treatment of sickle cell diseases, an evaluation of it anti- sickling activity was conducted in vitro on blood collected from voluntary homozygous $\mathrm{HbS} / \mathrm{HbS} S \mathrm{~S}$ sickle cell patients. This evaluation revealed that FACA $^{\circledR}$ syrup possesses an anti-sickling activity as the Hydrea in curative or preventive mode of treatment. Our results are in agreement with those of other authors who have previously demonstred that the combination of the powder from the root bark of both plants showed dose-dependent antifalcemic activity on sickling cell caused by sodium metabisulfite 8 . Also, an isolated compound from Z. zanthoxyloides root barks named Burkinabins A, B and C have showed interesting antisickling properties 9 . These results could support the traditional used of both plants in the treatment of sickle cell disease.

\section{CONCLUSION}

Acute and sub-acute oral toxicity studies in rats show that FACA $^{\circledR}$ syrup is well tolerated by animals under the study conditions. In addition, the efficacy of this herbal medicine is well proven by the results of the study. The overall findings confirm those already obtained with FACA Capsule which has a long history of use, and the use of FACA $®$ syrup can be recommended against sickle cell disease. However, it is necessary to supplement these preclinical data with clinical investigations of its efficacy and safety on human.

\section{CONFLICTS OF INTERESTS}

The authors have not declared any conflicts of interests.

\section{REFERENCES}

1. O.M.S. Stratégie de l'OMS pour la médecine traditionnelle pour 2014-2023. 2013; 72. Available from:

http://www.who.int/about/licensing/copyright_form/en/ind ex.html

2. OMS. Stratégie de l' OMS pour la Médecine Traditionnelle pour 2002 - 2005. 2002;78.

3. WHO. Sickle-Cell Disease: A Strategy For The WHO African Region Report of the Regional Director. 2010.

4. Cook GC. Manson's Tropical Diseases, 21st Edition PDxMD : Infectious Diseases, Volumes One. 2003; 37:2003.

5. OMS. Drépanocytose, Rapport du Secrétariat. Cinquanteneuvieme assemblée mondiale de la santé. Point 114 l'ordre du jour provisoire. 2006; 6.

6. Grosse SD, Odame I, Atrash HK, Amendah DD, Piel FB, Williams TN. Sickle cell disease in Africa: A neglected cause of early childhood mortality [Internet]. Vol. 41, American Journal of Preventive Medicine. Elsevier Inc.; 2011 [cited 2020 Aug 28]. Available from:

https://pubmed.ncbi.nlm.nih.gov/22099364/

7. Meier ER, Miller JL. Sickle cell disease in children [Internet]. Vol. 72, Drugs. NIH Public Access; 2012 [cited 2020 Aug 28]. p. 895-906. Available from: /pmc/articles/PMC3899685/?report=abstract

8. Guissou IP, Sawadogo M, Sawadogo A, Ouattara A. étude de l'efficacité antidrepanocitaire de gelules faca chez les enfants en milieu hospitalier de Ouagadougou (chn-yo). Pharm Méd trad afro. 1995; 29-36.

9. Ouattara B, Jansen O, Angenot L, Guissou IP, Frédérich M, Fondu $\mathrm{P}$, et al. Antisickling properties of divanilloylquinic acids isolated from Fagara zanthoxyloides Lam. (Rutaceae). Phytomedicine [Internet]. 2009 Mar [cited 2020 Aug 28]; 16(2-3):125-9. Available from: https://pubmed.ncbi.nlm.nih.gov/19110407/

10. Ouédraogo GG. Etude de la toxicité d'extraits de poudre d'écorces de racines de Calotropis procera (ait.) R.br. (Apocynaceae), composante du FACA®, phytomédicament utilisé au Burkina Faso. THESE UNIQUE, Dr ès Sci d'Application Pharm Univ Ouagadougou. 2015; 211.

11. Nikiema JB, Ouattara B, Semde R, Djierro K, Compaore M, Guissou IP, et al. Promotion de la Médecine traditionelle du Burkina Faso : essai de développement d'un Médicament antidrépanocytaire, le Faca. In: african traditional medecine day. 2010. p. 52-7.

12. Ouedraogo $\mathrm{S}$, Traoré $\mathrm{S}, \mathrm{O}$ uédraogo JCW, Koala M, Belemnaba L, Ouédraogo N, et al. $<$ p $>$ Quality control and standardization 


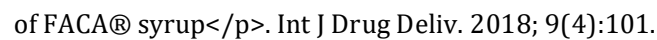

13. Ouédraogo JWC, Kini FB, Belemnaba L, Ouédraogo $S$. Standardisation de la poudre des écorces de racine de Zanthoxylum zanthoxyloides en vue la production d'un phytomédicament antidrépanocytaire pédiatrique. J la Société Ouest-Africaine Chim. 2015;040:24-30.

14. OECD. OECD/OCDE 423 OECD GUIDELINE FOR TESTING OF CHEMICALS Acute Oral Toxicity-Acute Toxic Class Method [Internet]. 2001 [cited 2019 Aug 10]. Available from: https://ntp.niehs.nih.gov/iccvam/suppdocs/feddocs/oecd/oe cd_gl 423 .pdf

15. Oecd/Ocde. Lignes directrices de l'ocde pour les essais de produits chimiques-Étude de toxicité orale à dose répétée pendant 28 jours sur les rongeurs. 2008; (11):1-15.

16. Seck M, Sall C, Gueye PM, Seck I, DiouMl MD, Lembachar Z, et al. Etude de l' activité antifalcémiante d ' extraits de racines de Leptadenia hastata. 2015; (June).

17. Sawadogo S, Sanou SD, Dabire P, Belemtougri GR, Sawadogo L, Leiris J De, et al. Activité antifalcémiante d' extraits de trois plantes médicinales du Bukina Faso : Jatropha curcas, Khaya senegalensis et Dichrostachys cinerea Antisickling activity of extracts of three medicinal plants of Bukina Faso : Jatropha curcas , Khaya senegale. 2017; 11(October):2016-27.

18. Seck M, Sall C, Gueye P, Seck I, Dioum M, Lembachar Z, et al. Etude de l'activité antifalcémiante d'extraits de racines de Leptadenia hastata Decne. (Asclepiadacae). Int J Biol Chem Sci. 2015 Sep 9; 9(3):1375.

19. United Nations. Globally Harmonized System of Classification and Labelling of Chemicals (GHS) [Internet]. ST/SG/AC.1. 2017 [cited 2019 Aug 10]. Available from: https://www.unece.org/fileadmin/DAM/trans/danger/publi /ghs/ghs_rev07/English/ST_SG_AC10_30_Rev7e.pdf

20. Ogwal-okeng JW, Obua C, Anokbonggo WW. Acute toxicity effects of the methanolic extract of Fagara zanthoxyloides ( Lam .) root-bark. 2004;(January).

21. Kinda PT, Guenn S, Compaor M, Bayala B, Ciobica A, Belemtougri R, et al. Toxicological characterization and central nervous system effects of Calotropis procera Ait . aqueous extracts in mice. 2019; 12(7):329-36.

22. Ouedraogo GG, Ouedraogo M, Lamien-sanou A, Lompo M, Olga M, Guissou PI. Acute and Subchronic Toxicity Studies of Roots Barks Extracts of Calotropis procera ( Ait.) R. Br Used in the Treatment of Sickle Cell Disease in Burkina Faso. Br J Pharmacol Toxicol. 2013;4(5):194-200.

23. Ouedraogo GG, Ilboudo S, Ouedraogo N, Ouedraogo S, Diallo D, Guissou PI. Phytochemical study and cardiovascular toxic effects investigation of root barks powder and extracts from calotropis procera (ait.) R.BR. World J Pharm Res World J Pharm Res [Internet]. 2016 [cited 2020 Sep 8];5(9):299-316. Available from: www.wjpr.net

24. Mukinda JT, Syce JA. Acute and chronic toxicity of the aqueous extract of Artemisia afra in rodents. 2007;112:138-44.

25. Li X, Luo Y, Wang L, Li Y, Shi Y, Cui Y, et al. Acute and subacute toxicity of ethanol extracts from Salvia przewalskii Maxim in rodents. J Ethnopharmacol [Internet]. 2010; 131(1):110-5. Available from: http://dx.doi.org/10.1016/j.jep.2010.06.012

26. Pariyani R, Ismail IS, Azam AA, Abas F, Shaari K, Sulaiman MR. Phytochemical Screening and Acute Oral Toxicity Study of Java Tea Leaf Extracts. 2015; 2015.

27. Nwozo SO, Tijani HA, Oyinloye BE. Toxicological Evaluation of Methanolic Extract of Zanthoxylum zanthozyloide Stem Bark Toxicological Evaluation of Methanolic Extract of Zanthoxylum zanthozyloide Stem Bark. 2011;(January 2011).

28. DEMBELE S. M. F. Etude pharmacothérapeutique du phytomédicament antidréranocytaire $\cdot$ FACA $®$ : proprietés pharmacologiques chez l'animal et efficacite thérapeutique chez l'enfant drepanocytaire au CHUY 0 de ouagadougou These. Universite de Ouagadougou; 2001.

29. Ouédraogo, Moustapha. Etude pharmaco-chimique du macéré aqueux des écorces de racines de calotropis procera Ait (Asclépiadacée) utilisées en phytothérapie de la maladie drépanocytaire au Burkina Faso. 2001. 